Modern Asian Studies 36, 1 (2002), pp. 103-139. (C) 2002 Cambridge University Press Printed in the United Kingdom

\title{
Anxieties of Attachment: The Dynamics of Courtship in Medieval India
}

\author{
DAUD ALI \\ School of Oriental and African Studies, University of London
}

The copious literature on love in early India has most recently been interpreted as a variant of the universal experience of human sexuality. Studies have rooted the uniqueness of Indian ideas either in theological conceptions of the immanent and transcendent, or in the particularity of the parent-child relation in India. ${ }^{1}$ Whatever the insights of such scholarship, two major problems relevant to this essay are its positioning of a 'civilizational' backdrop as its subject of analysis-either 'India' or 'Hinduism' - and, particularly with the former approach, the subsequent application of what has been called the 'repressive hypothesis' to the Indian material, which poses the 'transcendent' principles of Indian civilization in a restraining role over those deemed lifeaffirming or immanent. This essay will offer an alternative to these interpretations by placing conceptions of romantic love in medieval India within their social and discursive contexts, and connect up the discourses on self-discipline in medieval India with those of love in a more historically specific and illuminating way.

Whatever the claims of nationalist or humanist scholars, contextualization is manifestly relevant in the case of romantic love for the simple fact that the sources quite conspicuously fail to posit a universal

${ }^{1}$ For the former, see Wendy Doniger O'Flaherty, Siva: The Erotic Ascetic (New York: Oxford University Press, 1973), and Lee Siegel, Fires of Love, Waters of Peace: Passion and Renunciation in Indian Culture (Honolulu: University of Hawaii Press, 1983). These scholars have argued, using the paradigm of J. C. Heesterman, that Hindu thought may be best characterized by the tension between the immanent world and the drive for the transcendent, abandon for the senses and abandonment of the senses. David Shulman has applied the following model to Indian kingship, arguing that the king's personality reveals this larger civilizational conflict; David Shulman, The King and the Clown in South Indian Mythology (Princeton: Princeton University Press, 1985). More recently, he has used this argument within an 'historical' frame to discuss the sexuality of Nāyaka kings in late-medieval south India in Velcheru Narayana Rao, David Shulman, and Sanjay Subrahmanyam, Symbols of Substance: Court and State in Nayaka Period Tamilnadu (Delhi: Oxford University Press, 1992). For the latter interpretation, see Sudhir Kakar and John Munder Ross, Tales of Love, Sex and Danger (Oxford: Basil Blackwell, 1986).

o026-749X/02/\$7.5 $0+\$ 0.10$ 
subject for their discourses. In fact, they say quite explicitly that those fit to enjoy erotic love were to have four qualifications which distinguished them from other members of society: good birth, wealth, urbanity, and beauty. ${ }^{2}$ Romantic love, as revealed by the evidence we have available to us from early medieval India, was a specifically hierarchical and class-defined institution. Its most immediate context was typically the royal court or the associations of refined and noble city-living men who were drawn to the court for their livelihoods. Judging from its prevalence in Sanskrit literature, we may also say that the institution of romantic love in India grew up with the evolution of a particular type of class society. Its terminology is covalent with broader conceptions of affiliation in that society, and some of its key dynamics reflect the preoccupations of that society. Its rise and prominence may be effectively traced through the proliferation and development of Sanskrit ornate poetry, or kāvya, at royal courts from the second century $\mathrm{AD}$, but particularly from the fourth-fifth centuries.

The evolution of karrya in both form and content exhibits an increasing complexity in manners and conventions among the courtly elite from Gupta times. This was as much the case with love as it was with elements of personal comportment, social disposition and ethical self-fashioning. If we compare the story cycle of the courtship of Nala and Damayantī as it appears in the Mahäbhärata, dated perhaps to the first centuries of the Christian era, with the Naisadhĩyacaritam of Śn̄harșa, composed during the reign of the Gāhaḍvāla king Jayacandra of Kanauj (1170-1193), it is immediately apparent that romantic love had become a far more discursively elaborate process, one imbricated with the concerns of personal refinement and 'ornamented' with various embellishments which characterized the wider preoccupations of courtly life. The development of the 'form' and genre which separates these two cycles is itself an index of the evolution of a tradition of courtly love in medieval India. Erotic love emerged as one of the chief preoccupations of kāvya, so much so that by the time of Bhoja (eleventh century) it was deemed to be the most eminent of all aesthetic sentiments.

Courtly poetry, however, must be put in the context of other types of sources. This essay will also draw from the sāstric literature regarding dharma, artha (acquisition) and kāma (pleasure). Particu-

\footnotetext{
2 See Vātsyāyana, Kāmasūtra, ed. Goswami Damodar Shastri (Benares: Jaikrishnadas and Haridas Gupta, 1929), 1.4.1-2; compare with the later Kaviśekhara Jyotiśvara, Pañcasāyaka, ed. Dhundhirāja Śāstri (Benares: Jaikrishnadas and Haridas Gupta, 1939), 1.4.
} 
larly relevant are the texts on kāma-most notably Vātsyāyana's Kāmasütra (c. third to fifth centuries $\mathrm{AD}$ ), which often contain, among other relevant topics, sections devoted entirely to the characteristics and relations of lovers, and perhaps even more important for the interpretations which follow, are the treatises on artha and niti (policy) which together roughly correspond to the domain of polity. Taken together, these prescriptive knowledges had as their audience the congeries of men and assemblages of lords who formed the ruling élite of Indian courts. Also important are Sanskrit inscriptions, usually royal orders (śäsana) which mention in their preambles particular conceptions of the relations between agents at court. Finally, the gnomic and didactic sayings, aphorisms, or single-stanza poems often generically referred to as subhạsita (literally 'well-spoken', sayings or counsels which circulated orally among the circles of the élite and which echo through the breadth and interstices of Sanskrit literature), give us a fascinating insight into the mental structures of the ruling classes of medieval India. Read together, these sources illuminate the preoccupation of erotic love in a different way.

Understanding the discursive provenance of the terms which come to refer to romantic love in medieval India is particularly difficult because their inter-relation shifts between aesthetic and religious traditions, and over time. Nevertheless, reading the early texts, one can distinguish between two different types of words: those which refer to the physical desire for and pleasure arising from sexual union, terms like kāma and rati; and those terms which refer to the more general dispositions of adoration, attachment, affection, and participation that lovers were to share in varying degrees with one another, typically designated by terms like rāga, anurāaga, śringāara and bhakti. In drawing this distinction, I am not suggesting that these terms functioned to distinguish between physical sex and a higher form of love. Both sorts of terms must be distinguished from sexual union itself (sambhoga, surata) and were uniformly deemed to arise within the mind/heart of the lover. Some schools of theology certainly did counterpose some of these terms against one another, like Krṣna in the Gĩta who recommends bhakti over kāma. But in the case of the relations between lovers as described in the Kāmasūtra, Nātyaśăstra, and other texts of kârya tradition, these two types of terms are seen as related and complementary, rather than opposed. Moreover, the admonitions to avoid too much kāma, which formed as much part of the Kammasutra tradition as it did that of the 'religious' sphere, apply equally to the terms of bhakti and anurāga. These latter terms 
could encompass or include kāma within themselves. This does not mean, however, that these two sets of terms were identical. The latter set of terms, particularly those of bhakti and anurāga, were used more generally to characterize relations between various men in medieval Indian society. The rise of these terms in political discourses parallels precisely the rise of kārya as a discursive form and love as a courtly theme. And it is through attention to the wider usages of these terms that we may learn something of the preponderance of erotic themes among the ruling discourses of medieval India.

This essay will not assume that modes of self-discipline in early India should be seen as repressive forces restraining innate passions and desires. Modern scholars have too often understood mastery and pleasure as autonomous and conceptually opposed domains. Their interaction has been interpreted as the more or less successful impingement of the repressive forces, usually in the form of transcendentalizing brahmanical orthodoxy on the 'erotic' drive of the popular or Purānic. Much work remains to be done in the Indian context even from this vantage point. In European sociology, Norbert Elias has been instrumental in suggesting that development of mechanisms of restraintor 'civilizing processes' — such as manners and courtesy have reflected social compulsions. In the Indian context, the history of erotic love thus could be connected to the growth of courtly manners within a framework akin to the now obsolete paradigm of 'Sanskritization'.

In European sociology, the alternative to this tradition of scholarship has been most expressly articulated by Michel Foucault. This 'repressive hypothesis', as Foucault has argued, is a distorted selfperception of modern bourgeois societies. Disciplinary mechanisms have been far more productive of desire than either their architects or opponents have assumed. Foucault has read disciplinary practices in pre-bourgeois societies as part of regimes of self-discipline connected with the formation of ethical subjecthood and agency. This essay will read the 'repressive traces' in courtly texts not as vestiges of a network of codes negating pleasure, but as disciplines integral to the production of desire. While there is certainly an antagonistic relation between self-mastery and sensual pleasure in the courtly texts, the effects of this relation were not always negative in relation to the pursuit of pleasure. While for the ascetical life the conquest of the senses involved a subdual, or sublimation of pleasure, in the courtly contexts this same conquest entailed a cultivation of desire. The enjoyment of pleasures was thus not understood as a straightforward release of libidinal impulse, as is clear from Vātsyāyana's elo- 
quent argument in the Kammasütra that kāma required the application of 'means' (upāya). ${ }^{3}$ These means, the 'rules of engagement' that the erotic texts lay out in great detail, both through specific conventions and general principles, were quite explicitly understood as a form of self-mastery. The desires of the courtly texts, thus, are encouraged and formed positively and internally by the call to self-mastery. In fact, according to the texts, the proper exercise of pleasure was a form of self-mastery. Self-mastery did not bear down upon desire, but instead cultivated and operationalized it.

A short example from the Nala story will adumbrate the theme I wish to develop here. In the Mahābhärata's account of the initial lovesickness of Nala and Damayantī, we find the following description of Nala: 'unable to bear his desire in his heart, Nala at once left secretly and sat in a grove besides the women's quarters. ${ }^{44}$ In Śñharșa's rendition, this event is preceded by a rather long conceit about the god Kāmadeva's attempt to subdue Nala through the form of Damayantī-a conceit which is significant in itself as we shall see-in which Damayantî's excellence is said to be 'made by the king the guest of his ears'. After Damayantī enters Nala's heart, Śrīharșa says that the

powerful Nala, though consumed by desire, did not ask the king of Vidarbha for the hand of his daughter, as the proud would rather renounce both life and happiness than forsake the single vow never to beg. Feigning to be depressed on account of something, he concealed the succession of his sighs caused by his separation from her, and denied his paleness by attributing it to an excess of camphor in the sandal paste applied to his body. Luckily, even while in company, he was able to conceal during the vin̄a music both his words uttered to his beloved under delusion, as well as the fact that he fainted. The king, who had a reputation of being the foremost among those whose senses were conquered, was ashamed when the irresistible power of Kāmadeva became, by degrees, manifest in him. Neither the power of discrimination nor other virtues could restrain Nala's disquiet; for where there is desire, Kāmadeva produces an unrest that is never restrainedsuch are the ways of the world. When, in spite of his efforts, he became unable to sit in the royal assembly even for a moment, without betraying signs of being in love he desired to retreat to a secluded place under the pretext of recreation in his pleasure garden. ${ }^{5}$

While both accounts precede Nala's entrance into the garden, where in the Naisadhĩyacaritam his problems worsen as a host of flowers

${ }^{3}$ Kāmasūtra 1.2.18-24.

${ }^{4}$ Mahäbhārata, ed. V. S. Sukthankar and S. K. Belvalkar (Poona: Bhandarkar Oriental Research Institute, 1961-), 3.50.17-18.

${ }_{5}$ Naisadhĩyacaritam, ed. Narayana Rama Acharya (Bombay: Nirnaya Sagara Press, 1952), $1.49-55$. 
afflict his mind and make him pine even more, Śrīharșa's elaboration is significant. He dwells on the afflictive condition of Nala's growing affection for Damayantī, whether as the designs of Cupid or simply as an indication of his 'weakness' at court. How should we understand the elaboration of distress and 'shame' (säpatrapatā) at the manifestation of his condition, and his efforts to conceal his feelings before members of the court? Should we see this elaboration as the result of increased imposition on the part of brahmanical orthodoxy upon the desires of the poem's hero? The approach here will instead see the elaboration of romantic love not merely as part of the 'restraining' compulsions of the social but also as part of the productive agency that such compulsions encouraged.

\section{The Self and its Discipline}

We may begin with the conception of the self in early medieval India. While courtly theories of the self are related to and draw from those formulated by monastic and liturgical orders of post-Vedic India, it would seem that the worldly life of the court presented its own set of exigencies and problems which demanded particular strategies and solutions. This was so much the case that the care and discipline of the self was foundational for all of the 'scientific' knowledges which were to organize human life, and particularly (for our purposes) that of niti, or 'policy'. The problems taken up in these texts were 'ethical' to the extent that they sought to formulate the postures and dispositions that a man was to take with those around him. This ethical training, according to the texts on polity, was to begin with an active relationship toward oneself. The basic idea of the self we find mentioned in the courtly texts and manuals on political conduct was a concentrically arranged structure which may be represented visually, following Kāmandakī's Nìtisāra, in Figure $1 .{ }^{6}$ The central constituent of the self, which could stand in for the self as a whole, was the soul, or ātman. In Kāmandakī, the next element was the mind, or manas, but other formulations include entities like buddhi, cit, ahamkāra, collectively known as the 'internal organs' (antahkaranas). ${ }^{7}$ The outermost constituents of the self were the five

${ }^{6}$ Kāmandakī, Nītisāra, ed. and trans. Raja Rajendralal Mitra (Calcutta: Asiatic Society, 1869), 1.33-6.

${ }^{7}$ Kāmandaki is aware of this elision. He states elsewhere that 'perfect knowledge (vijñana), the heart (hrdaya), consciousness (citta), the mind (manas) and the intellect (buddhi) are synonymous and are caused by the ätman to discriminate between what 


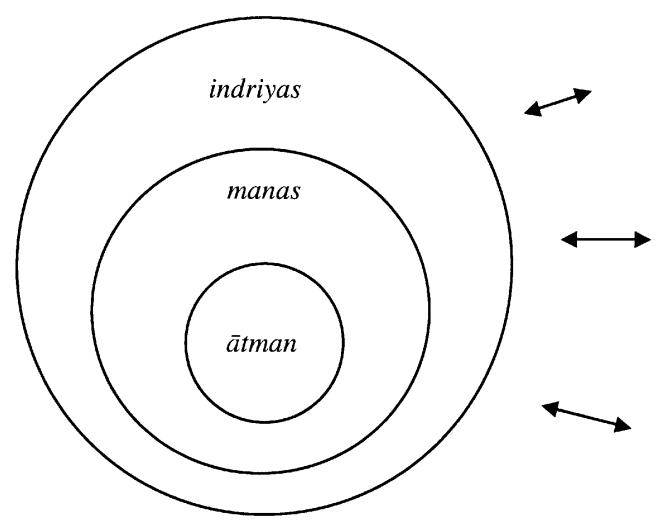

Figure 1.

sensory-organs or indriyas-ear, skin, eyes, tongue and nose-along with five other 'external' organs-the sex organ, the anus, hands, feet, and mouth, which together formed the ten faculties of action and cognition. Taken together, the constituents of the self formed a particular order which may be grasped in a number of ways. The spatial arrangement was concentric, and operated with a logic very similar to that of the court or the kingdom. The self's most important and defining element, the ātman, stood at the centre of the structure as its permanent core. It was comparatively inactive, preferring instead to act through the agency of less permanent sheaths which surrounded it in successive layers. Consequently, the outer layers of the self surrounding the atman were considered to be karanas'instruments' or 'means' of knowledge and action, ultimately in the service of their master, the ätman. The karanas were further divided into 'internal' and 'external' instruments or organs (antahkarana, bāhirkarana). Each of these organs had an activity (kriyā) appropriate to it, according to Kāmandakī. The most important of these were the sensory organs (indriyas) which had as their activities sound, tough, vision, taste and smell, while the other external organs performed speech, movement, the giving and accepting of objects, and excretion. The major activity of the sensory organs was of course to engage with their appropriate fields (vișaya). The more complex

should be done and what should not be done', Nìtisāra 1.3o. Elsewhere Kāmandaki includes the ätman along with the manas among of the antahkaranas, Nitisāra 1.35. This would seem atypical. He implies in 1.30 that the ätman has a more determinative role. For different formulations of the antahkaranas, see John Grimes, A Concise Dictionary of Indian Philosophy (Albany: SUNY Press, 1996), s.v. 
processes of the internal elements of the self presupposed the activities of the sensory organs. In a process called samkalpa, the mind organized indeterminate sensory data into determinate perceptual forms. From this process a series of both affective and volitional states arose like doubt, imagination, and pleasure and desire. In this structure, the mind was crucially situated: it formed the link between the outer sense organs and the more internal parts of the self. It was the first element of sentience in perception.

Relations between elements of the self were not simply based on function, but they also implied hierarchy and mastery. One of the earliest images of the self was that of a chariot. Each of the self's components was analogized to a part of the chariot as driven by its master, the attman. In an eighth-century inscription of the Rāșțrakūta king Amoghavarsa, the soul is compared to the king, the mind his minister, the group of senses his circle of feudatories, and speech and the other organs to servants conforming to the prescribed rules of dharma ${ }^{8}$ This is repeated by spiritual discourses as well. A thirteenth-century Śaiva Siddhāntan text, the Civajñānapōtam, contains a similar description of the soul ruling over the inner organs of manas, cit, buddhi, ahaṃāra just as a king rules his kingdom through his ministers. ${ }^{9}$ Such metaphors not only underscore the evolution of political structures and the importance of the social relations of the court in imagining the insides of people, but just as importantly, reveal something about the actual relation that the twice-born man was to have with himself. The normal and proper 'functioning' of the self was one that implied relations of internal hierarchy, mastery, and even coercion. The mind's activity of resolving indeterminate sensory matter received from the indriyas into coherence (samkalpa) was not simply a generic psychic process, but a marshalling and discipline of the senses as instruments in the same manner as a minister bearing the burden of rule effected the will of his master in regard to his feudatories. The mind was ruler of all of the external organs through which a person communicated with and commanded the objects of the senses, which were regarded as its 'domains', or fields (visaya) of mastery.

So it is that we find that the first dictum of niti or policy in the theoretical texts is that the king should master the various elements of his own self, particularly his senses. Mastery or 'conquering' of the senses

\footnotetext{
${ }^{8}$ Epigraphia Indica 18 (1925-26), no. 26, p. $255^{-}$

9 Meykanda Deva, Civajñānapōtam trans. Nallaswam: Pillai (Dharmapuram: Gnanasambandam Press, 1945), 4 .
} 
(indriyajaya) was of utmost importance for the king. The texts on polity are emphatic on this point. According to Kāmandakī, the conquest of the senses made a candidate fit for the knowledge of the śăstra, as only one who had mastered his senses was fit to receive its meaning. ${ }^{10}$ This mastery of the senses was effected through and synonymous with selfdiscipline or vinaya. ${ }^{11}$ The term vinaya, one of the most generic virtues of courtly life, was conceptually (and etymologically) related to concepts of proper 'policy' (nīti) and proper 'directed conduct' (naya) integral to life at court. While naya and nitti generally referred to conduct in relation to the external world, vinaya most often denoted conduct towards oneself. The position of the texts is that an individual's conduct and policy at court presupposed and sprang from 'self-policy' or self-discipline. As Kāmandaki puts it, 'self-discipline (vinaya) is the root (mülam) of directed conduct (naya)'. ${ }^{12}$ This is because, according to Kāmandakī, perfect knowledge of the śástra could only be obtained through discipline. ${ }^{13}$ For Kautilya, self-discipline in the various knowledges is the cause of mastery over the senses, which is in turn considered the essence of the śăstra on policy (he calls it the whole of his teaching). ${ }^{14}$ In either formulation, we begin with the practice of selfdiscipline as the means to effect mastery over the senses. So the first coercion that the king was to exercise, which was to form the basis of all his subsequent policies, was in respect to his own mind and body. Megasthenes' observation about brahmins would seem to apply, judging from the texts on nitti, to the king as well: 'they regard the body as being the fruitful source of wars, and, as we have already shown, fight against it like soldiers in battle contending against the enemy'. ${ }^{15}$

So far we have explored the mastery of self in relation to the pursuit of artha, but perhaps not surprisingly, the mastery of the senses was also deemed a prerequisite for the proper pursuit of kāma. Judging from the texts, self-discipline was as general a characteristic of the people at court in love as it was in other matters. The Nātyaśăstra, for example, includes dhĩra, self-control, as an integral characteristic in all its categorizations of nāyakas. ${ }^{16}$ The penultimate verse of

${ }^{10}$ Nìtisāra $\mathbf{1 . 2 2 .}$

11 Ibid.

12 Nìtisāra 1.21.

13 Ibid.

14 Kantīlya Arthaśāstra, ed. and trans. R. P. Kangle, 3 vols (Delhi: Motilal Barnasidass, 1988), 1.6.1-3.

15 Indika, trans. J. W. McCrindle (London: Tnübner, 1877), Fragm. 54.

16 Nātyaśästra, ed. Manomohan Ghosh, 2 vols (vol. 1, Delhi: Manisha Granthalaya, 1967; vol. 2, Calcutta: Asiatic Society, 1956), 34.18-19. 
the Kämasütra recommends that 'he who knows the principles of this śästra is one who has conquered his senses (jitendriya) and will be able to conduct himself in the world and firmly guard dharma, artha and $k \bar{a} m a .{ }^{17}$ It is perhaps peculiar to conceive of the enjoyment of pleasures as entailing a conquest of one's senses. While the true dynamics of this conquest will become apparent in the following sections, Vātsyāyana's general definition of kāma is telling enough for the moment: 'the activity of the sense-organs, the ear, the skin, the eye, the tongue and the nose, when favourably disposed in their fields of operation, as overseen by the mind (manas) along with the soul (ätmasamyukta). ${ }^{18}$ The senses must be engaged, 'in contact' as the succeeding verse specifies, with their particular fields (vișaya), but simultaneously they were to be 'overseen' or 'directed' by the mind. The word here is adhișthita, literally to 'stand over' or 'superintend'. This was to be the particular posture of the mind to the senses both in general and particularly with regard to pleasure. Thus, 'victory' over the senses did not entail their eradication, but rather their subordination and control by their proper superintending agent, the mind. The mind ruled the senses in the enjoyment of pleasure and it was in the mind that the experience of $k \bar{a} m a$ was thought to arise, through resolution, giving rise to its epithets 'mind-born' (manasija, manoja) and 'willborn' (samkalpaja). We shall return momentarily to the importance of the mind in the actions of the self, but here it will suffice to note that the proper enjoyment of pleasure is not conceived of in opposition to self-discipline and mastery of the senses, but as a proper function of it.

\section{The Dangers of the Senses}

Why did the senses need to be conquered; why was such selfdiscipline necessary? Each of the five senses, according to the Nitisāra, was sufficient to bring about the ruin (vināśa) of a person. ${ }^{19}$ Kāmandakī gives an example, for each sense, of an animal killed by its pursuance-a deer lured by the melodious sound of the hunter's flute, an elephant ensnared by his desire for the touch of a sheelephant, and so on. For man, the vices that could arise from the

\footnotetext{
17 Kāmasūtra 7.2.58.

18 Kāmasūtra 1.2.11.

19 Nítisāra 1.52.ff
} 
improper influence of the senses were many, and a list of six enemies (sadarivarga) is routinely cited by courtly texts as consisting of desire (kāma), anger (krodha), greed (lobha), conceit (māna), rashness (mada) and delight (harsa).$^{20}$ Avoiding these effected the conquest of the senses, according to Kauțilya. ${ }^{21}$ These 'enemies', however, like the senses themselves, were not absolute. All of them in their proper measure could bring benefit, but in excess were capable of transforming themselves into vices destructive of a man's interest and fortune. Kāmandakî's commentator, for example, explains harșa, a term usually positive in connotation, as 'joy taken in the killing of beings without sufficient reason'. ${ }^{22}$ A number of vices arose from anger and desire, the relative ranking of which was a matter of debate among the śăstra authors. Despite their status as 'enemies', anger and desire had their utility - the former being necessary for the suppression of evil and the latter for the enjoyment of fruits-in the words of one author cited by Kautilya. ${ }^{23}$ Though Kautilya seems to differ on this point, he elsewhere asserts that the king should not deprive himself of pleasures but serve käma without contravening artha and dharma. ${ }^{24}$

Control over the senses, then, was an 'avoidance of errors' (avipratipatti) in relation to each of the senses. ${ }^{25}$ These errors most often took the form of an indulgence, an excessive pursuance of a particular sense-domain. The manas, as the superintendent of the senses, was ultimately responsible for the control of the senses, and in the case of their straying, was complicit in such excess. Kāmandaki says that the mind excites (prerayata) the senses with greed for senseobjects as if they were meat preparations. ${ }^{26}$ Goaded on by an undisciplined mind 'running wildly like an elephant in the forest of the sense-objects', ${ }^{27}$ the senses fixated on their objects to the detriment of the self. In the hierarchic logic of the self's structure, the com-

${ }^{20}$ Arthaśāstra 1.6.1;1.7.1; Nìtisāra 1.57; Kāmasūtra $5 \cdot 5 \cdot 38$.

21 Arthaśāstra 1.6.1.

22 Nitisāra 1.57 comm.

23 Arthaśāstra 8.3.8-12.

${ }^{24}$ Arthaśāstra 8.3.13-22. Kautilya differs with the above cited author, Bhāradvāja, over the issue of the relative seriousness of kamma and krodha and not on their status as vices as such. His remarks are, thus, somewhat curious, given that Bhāradvāja, not considering these qualities as vices, is not concerned at all with their relative seriousness. For Kautilya's positive remarks on kāma, see Arthaśāstra 1.7.3.

${ }^{25}$ Arthaśāstra 6.1.2.

${ }^{26}$ Nitisāra 1.29.

27 Nitisāra 1.27. 
mand of the mind included mastery over all that he should command. The conquest of the senses, in other words, began with the mind. Kāmandakī asks 'how can one who cannot subdue the mind (manasah sannirbahane), conquer the earth bounded by the oceans?'28

The consequences of the mind and senses gone astray were manifold. They could involve a violation of the hierarchical principles of 'law', or dharma. The śāstric literature cites such examples in abundance. The Bhoja king Dāṇakya, for example, seeing a brahmin maiden while hunting, abducted her with desire, and perished along with his family and kingdom as the result of her father's curse. ${ }^{29}$ Such admonitions would seem to imply a 'repressive' code. The pursuit of sensual pleasures was not to contravene the proper exercise of dharma. But in fact, they form one among a much more varied set of dangerous eventualities which awaited the man who indulged his senses. The excessive pursuit of one's senses left one exposed to one's enemies. So a king overcome by his desires for the objects of the senses was vulnerable to attack like an elephant. ${ }^{30}$

But the most general danger in the pursuit of the senses was what various sources, both courtly and monastic, called 'attachment'. In its broadest sense, attachment referred to life in the world, as opposed to liberation from the world. More precisely, attachment referred to a specific relation of involvement on the part of the self, through the mind and the senses, with the outside world. Renunciative philosophies attributed it to different cognitive and mental errors. ${ }^{31}$ Release and liberation from the fetters of worldly life thus required a detachment from the objects of the senses. 'Attachment', however, was an equally important concern at court. One of its implications features prominently in medical texts concerned with the health of the king, particularly around a disease known as rājayakșman, 'the royal disease' or 'king of diseases'. ${ }^{32}$ Caraka's medical treatise gives a detailed account of its origin, etiology and treat-

${ }^{28}$ Nìtisāra 1.36 .

${ }^{29}$ Arthaśāstra 1.6.5; also Kāmasūtra 1.2.44.

${ }^{30}$ Nìtisāra 1.40 .

31 See the discussion of the term rāga in relation to orthodox schools of philosophy in Surendranath Dasgupta, A History of Indian Philosophy, Vol. 1 (Cambridge: Cambridge University Press, 1922).

32 The double-meaning of rājayaksman is noted and discussed by F. Zimmerman, The Jungle and the Aroma of Meats: An Ecological Theme in Hindu Medicine (Berkeley: University of California, 1987), p. 177. 
ment. According to Caraka, Dakṣa, or Prajāpati, gave his twentyeight daughters to the moon (soma) in marriage. But the moon became overly attached (atisakta) to one of these daughters, Rohinī, and neglected to take care of his body, which suffered a diminishment of unctuousness due to loss of vital fluids. ${ }^{33}$ Because the moon married all of the daughters of Prajāpati but did not deal with them equally, being excessively attached to one, Prajāpati became angry and exhaled his anger from his mouth. And 'despised by the great, treating his wives unequally, filled with rajas and weakness, the moon was attacked by yakșmā. ${ }^{34}$ Prajāpati eventually allowed the moon to be treated by the physicians of the gods, the Aśvins who cured him. Yakșma was then despatched to the human world by the Aśvins, where it entered into human beings through various etiologies.

The invective here is not against pleasure as such. The cause of the moon's affliction is his over-attachment to one of his wives and the consequent neglect of his others, literally the 'non-enjoyment' (asambhoga) of his other wives. ${ }^{35}$ Among the etiologies of the disease in the human world was 'excessive thinning' (atikarśana) which could be caused by a variety of factors: pining for a lover (utkanthā) or overindulgence in sexual intercourse (ativyavāya). ${ }^{36}$ The emphasis here is on 'excessive' sensual indulgence which initiated a physical wasting.

The final book of the Raghuvamśa ends with the blight of rājayaksman, the story of king Agnivarna. Installed on the throne by his father, the king conducts his affairs for some years in person, and then consigns them to his ministers, and devotes himself wholly to the pursuit of pleasures. Kālidāsa describes at length the king's dalliances with the various women of the palace-his wives, courtesans, dancers and attendants. But he hints that all is not right.

Unable to bear even the interval of a single moment without the enjoyment of the objects of the senses (indriyarrtha), spending day and night in the indoors, he had no regard for his longing subjects. If upon the counsel of his ministers he deigned to give appearance (darśanam) to his expectant subjects, he did so by hanging a foot from the opening of a window. ${ }^{37}$

\footnotetext{
${ }^{3}$ Agniveśa Carakasamhitā, ed. and trans. R. K. Sharma and V.B. Dash, 3 vols (Varanasi: Chowkhamba Publications, 1983), 6.8.4 ff.

${ }^{34}$ Carakasamhitā 6.8.7.

${ }^{35}$ Carakasaminhitā 6.8.5.

${ }^{36}$ Carakasamhitā 6.8 .24

37 Raghuvaíśa 19.6-7.
} 
The dependants (anujizin) of his court bow and honour his extended foot. The king's neglect of his subjects and supplicants forebodes the worst. Though due to his power he remains safe from his enemies, he begins to thin (aksinot) from a disease 'born of attachment to pleasure' (ratirägasambhava). ${ }^{38}$ Agnivarṇa ignores the counsel of his physicians as rajjayakșman becomes apparent. His face pales, his voice weakens, he is unable to adorn himself, and can walk only when supported by his servants. Raghu's family Kalidāsa significantly compares to the sky with the moon on its last digit. The comparison is significant. The moon, or Soma, who was progenitor of the rains, and the waters, was the first victim of räjayakșma. His 'thinning', according to Caraka, was due to snehakșaya, specified by his commentator as the loss of semen and vital life fluid. ${ }^{39}$ The king's loss of fluid, like that of the moon, led to the inevitable 'drying up' of his sovereignty. The case of rajayaksma demonstrates that the enjoyment of sexual pleasures, which ordinarily caused a tumescence and plumpness of the body, could also lead, if improperly pursued, to the reverse process of desiccation, and in some cases even death. Agnivarna is not as fortunate as Soma; he eventually dies in his palace garden, attended by his ministers and the royal physician.

Overattachment and its attendant wasting was not seen as simply a dissipation resulting from pleasure itself, but instead as a disarticulation of selfhood. The wasting of rājayakșma could in some cases, Caraka tells us, be caused by excessive reducing (atikarśana) from prolonged pining for a lover (utkanțhā).$^{40}$ Vātsyāyana corroborates the list of in his ten 'stages of desire' (kāmasthāna). He begins with pleasure of the eyes (caksupriti), followed by a fixation of the mind (manasanga), and then the arising of 'resolve' (samkalpa utpatti). ${ }^{41}$ After a progression from the senses to the mind, which becomes slowly attached to the object of desire there is a steady progression of attachment, calibrated by symptoms, beginning with loss of sleep (nidrāccheda), physical emaciation (tanutā), turning away from (other) objects of the senses (vișayebhyo viāurtti), loss of shame (lajjāpranāasa), madness (unmāda), fainting (mūrcchā), and finally, as in rājayakșma, death (maranam). ${ }^{42}$ What is interesting in Vātsyāyana's account of

38 Raghuvamís $\mathbf{1 9 \cdot 4 8 .}$

39 Cited in Zimmerman, Jungle and the Aroma of Meats, p. 177.

40 Carakasamhitā 6.8.24.

41 The term samkalpa, as noted before, refers to the mind's organization of the diffuse sensations coming from the senses into desire, will or violation.

${ }^{42}$ Kämasūtra $5 \cdot 1 \cdot 4 \cdot 4-5$. 
the stages of attachment is the advice he gives to avoid the process of physical degeneration: 'when he sees desire progressing from one stage to the next, then, with the goal of preserving his own body from harm, he may approach another's wife. ${ }^{43}$ So self-preservation in the face of wasting from overattachment becomes the pretext for Vātsyāyana to prescribe not merely sexual relations, but the violation of patriarchal privilege by sexual relations with another man's wife. In some cases, then, the dangers of attachment could be avoided by entering into sexual liaisons rather than curtailing them. Dāmodaragupta says that while sexual intercourse with one's wife was necessary for progeny, sexual intercourse with servants (cetika) may be necessary for the abatement of sickness (from excessive desire). ${ }^{44}$ The problem of attachment was not about the morality of the sexual relationship itself, and did not take the form of a body of consistent interdictions against particular acts, behaviours or liaisons. It instead concerned the disposition that the self was to have with the external world as a whole. The senses posed the danger of a loss of self-mastery.

\section{Attachment and Autonomy: the Dynamic of Courtly Relations}

To grasp the full significance of self-mastery for courtly elites, it is necessary to see these problems from another angle. We have seen that there were, according to the policy manuals, good reasons for the noble man to avoid attachment to sensual pleasures. Further, his self-restraint was seen to be a token of his fitness to stand above his social inferiors. In this sense, the condition of self-mastery was always opposed to various states of dependence and slavery. In the courtly world, self-restraint was a mark of freedom.

The life of men at court may be viewed simultaneously in relation to two poles: svatantra, or 'dependence on oneself', and paratantra, 'dependence on another'. Terms for gaining one's livelihood by the agency of another were anujivin or upajivin. Much of the gnomic and didactic literature of the court denigrates the condition of dependence and elevates that of independence. A ninth-century inscription which records the Pratīhāra king Nāgabhațta’s defeat of Cakrayudha

43 Kāmasūtra $5 \cdot 1 \cdot 3$.

44 Kuttanimata 812, cited in Ganikavrttasangraha, ed. Ludwik Sternbach (Hoshīarpur: Vishveshvaranand Institute Publications, 1953), 3. 
of Kanauj, who was in the service of the Pāla king Dharmapāla, says that Cakrayudha had a 'lowly demeanour clearly obvious from his dependence on another' ${ }^{45}$ As the hero of one story in the fifteenthcentury Purușaparīkșa puts it: 'cowards, children and women live by taking refuge in others. ${ }^{46}$ Such attitudes, however, must be placed within a political context of multiple and complex dependencies. Most men of rank at court enjoyed varying degrees of automony by virtue of their service to higher lords as princes, generals, retainers, or ministers. It is these men who formed the larger audience for the prescriptive and aesthetic literatures of the court, and whose problems are embodied in these literatures.

Autonomy and dependence were often viewed in relation to the acquisition and disposition of wealth. What constituted independence in terms of wealth was a perennial theme for the moralists of the court. Again and again they are clear on this point. According to the vița in İśvaradatta's Dhürtavitasaṃvāda,

There are three ends of money: making gifts, enjoyment and hoarding. Of these gifts and enjoyment are superior, and hoarding has been censored. Why? In hoarding money there is no benefit, and being without benefit, it creates no satisfaction. Hence hoarding is improper. ${ }^{47}$

Bhartṛhari adds from another point of view:

Giving, enjoying and losing are the three ways through which the amount of one's wealth can be lessened. The wealth of a man who neither gives nor enjoys his wealth can only be lessened by the third way. ${ }^{48}$

Giving and enjoying, then, are the most honourable ways of disposing of one's wealth. Preserving money (nidhāna), on the other hand, was a sign of the vice of 'miserliness' (krpana). Significantly, the Purusaparīks $\bar{a}$ calls miserliness a form of cowardice (kātara): if a man is fearful about his life he was called coward; if he was fearful about his wealth he was known as a miser. ${ }^{49}$

Generosity, by contrast, was among the most praiseworthy of virtues, the proper complement to wealth itself. All the prescriptive texts are in agreement as to the good benefits of giving wealth, and

45 Epigraphia Indica 18 (1925-26), no. 13, p. 106.

46 Vidyāpati Thākkura Purușapariksșā, ed. Ganganatha Jha (Allahabad: Belvedere Steam Press, 1911), 1.3.2.

47 Dhūrtavitasamvāda, ed. and trans. Manomohan Ghosh (Calcutta: Manisha Granthalaya Ltd, 1975), 59 .

48 Śribhartṛhari, Subhāșitatriśati rev. and ed. Narayana Rama Acarya and D. D. Kosambi (Varanasi: Chaukhamba Sanskrit Sansthan, 1987), 1.34.

49 Puruṣaparikṣ̄a 1.7.1. 
verses abound in the aphoristic literature praising giving (dāna). Generosity was a sign of independence as it presupposed not only self-subsistence, but the ability to make others dependent upon oneself. Through generosity one became a refuge for others. Put more cynically, in the shrewd words of İśvaradatta's vița, 'making gifts was a means of bringing others under one's control. ${ }^{50}$ Generosity was the necessary complement of wealth according to texts on the court. Courtly aphorisms tirelessly reiterate that being generous (dätara) attracted others to oneself regardless of one's birth and other virtues. ${ }^{51}$ Considering that the concept of largesse formed the dominant 'rationality' in the redistribution of wealth among the ruling classes, its importance can hardly be underestimated. ${ }^{52}$

This ethic toward wealth, of spending or giving, could also contribute, in adverse circumstances, to sudden penury. Among kings and princes, the depletion of resources forced one to attend the court of a greater king. Similarly for others of rank, the loss of fortune portended the abandonment of one's own retinue and the entry into the service of others. This is precisely the background of that peculiar character of courtly life, who forms the comic and wry narrator of the bhäna monologue plays which have already been cited above, the vita. The vita was a well-regarded man, learned in the arts of pleasure, who according to Yaśodhara, the commentator on the Kāmasūtra, once led the lifestyle of the nāgaraka, but having subsequently consumed his wealth, was now dependent for his livelihood on courtesans and nāgarakas. ${ }^{53}$ The vita possessed all of the qualifications of the nāyaka except for financial independence, and therefore was deemed a lesser member of 'good society'. According to Ksemendra, the vita was broken by debts (rnena khandita). ${ }^{54}$ His knowledge of the affairs of pleasure, however, was legion, and in Sanskrit dramas he formed an advisor (mantrin) for nāyik̄ and nāyaka ${ }^{55}$ In the bhāna monologue plays, the vita walks through the courtesans' quarters in conversation with those he meets on the street. The Nätyaśästra places the vita among the mixed characters of the drama, who, despite his birth, knowledge and refinement, was unsuitable for the role

Dhūrtavitasamvāda $29^{+}$.

1 Nìtisāra 5.60 .

${ }^{52}$ See, for example, Ganikāurttasaingraha 82-101.

${ }^{53}$ Kāmasütra 1.4 .45 , and comm.

${ }^{54}$ Ksemendra Deśopadeśa in Ksemendralaghukāryasaingraha, ed. V. V. Rāghavacarya and D. G. Padhye (Hyderabad: Sanskrit Academy, 1961), 5.24.

${ }^{55}$ Kãmasūtra $\mathbf{1 . 4} 4.47$. 
of nayyaka because his poverty made him a low character. ${ }^{56}$ The leading character of a drama, the nayyaka, was one who succeeded in fortune, who was literally 'elevated' or 'lifted up' from adverse conditions. ${ }^{57}$ Such was the fate of the virtuous brahmin Cārudatta in Sundraka's Mṛchakațika. The play begins with Cārudatta's pathetic lament on his new-found, poignant verses which take their place among the best poetry on the subject. The 'burning' thing about poverty, according to Cārudatta, is that guests (atithi) avoid (parivarjayanti) a house of diminished wealth (g̣̣ham kșinārtham) and people slacken their friendship (sauhrda) to one whose support of wealth is destroyed. ${ }^{58}$ By the play's end, however, Cārudatta has gained a position of favour at the king's court which enables him to exercise his own favour and generosity once again.

Poverty in the eyes of Cārudatta, as in the hundreds of courtly maxims on the subject, was so painful because it prevented the display of generosity and favours which structured the relations between members of equal rank in the form of hospitality and friendship and relations between men of rank and their inferiors in the form of the provision of livelihoods. Ultimately, poverty destroyed one's autonomy and subjected one to greater and greater dependence on others. The anxiety over wealth apparent in the courtly aphorisms reflected a perception of the precariousness of autonomy within the chain of greater and lesser dependencies which characterized the feudal élite in medieval India. For every maxim that wealth and power drew retainers and made one a refuge of the world, another followed that losing one's wealth, and failure to provide sufficient honours, brought calamity. Good men would abandon a lord like a calf abandoning its mother's udder when its milk was dry. ${ }^{59}$ To round off the discussion, the ethical problem that faced men at courts was this: how was it possible to maintain autonomy within a world of dependence? How was a man to negotiate his relations with others precariously but ineluctably situated between the poles of autonomy and dependence? That this situation constituted a concern is clearly indicated by the persistent exaltation and derision of

${ }^{56}$ Nātyaśástra $34 \cdot 14^{-16 .}$

${ }^{57}$ Nãtyasáăstra 34.23.

${ }^{58}$ Súdraka, Mrcchakatika, ed. and trans. R. D. Karmakar (Poona: Aryabhushan Press, 1937), 1.12; 1.13.

${ }^{59}$ Nĩtisāra 5.63; see also Nĩtisāra 5.59, 62; Arthaśāstra 5.5.12; Cānakya, Cānnakyarājanīti, ed. Ludwik Sternbach (Madras: Adyar Library, 1969), 181. 
wealth and poverty, and the states of mastery and service they implied, within the discourses of the court.

The relation between superiors and inferiors, between relatively autonomous and relatively dependent agencies, was expressed through a specific and limited set of expressions and practices, several of which will be relevant for the discussion at hand. From the very inception of political discourses, but particularly from Gupta times, inscriptions and courtly texts frequently describe the relations of lords and their subordinates through the language of attachment. ${ }^{60}$ 'Attachment' in courtly discourses referred not merely to a person's disposition towards the external world in a general sense, but often, more specifically to the particular relationship he or she had with other individuals. That is to say, the most common form of attachment we find in the discourses of the court is one person's 'attachment' to another. The term most often used to describe this relation of attachment to another person is anurāga. The root rañj (lit. 'reddening') meant to be affected or attracted by someone or something. Preceded by the purposive suffix anu 'to follow', anurāgal anurakta had an even stronger sense of being 'attracted to' or 'attached to' someone. The allied term bhakti denoted a disposition of 'devoted participation' toward a superior agent which involved subordinate participation in one's master's lordship. A few examples will give a sense of this vocabulary. In the famous Junāgadh rock inscription, dated to the Gupta era in the fifth century AD, one Parnadatta, described as a servant (bhrtya) of the king Skandagupta, and appointed to rule Saurāștra, is described as 'devoted' (bhakti) and 'attached' (anurakta) to his lord ${ }^{61}$ An early sixth-century inscription from Eran records that the wife of one Goparāja, who died on the battlefield in the service of his lord Bhānugupta, being devoted (bhakti) and 'attached' (anurakta) to her husband, followed him to heaven on the funeral pyre. ${ }^{62}$ The famous court poet of Harșa (6o647), Bānabhațta, writing at the beginning of the seventh century, describes the kings from various countries who attend the court of

\footnotetext{
${ }^{60}$ For two pre-Gupta examples, see Kharavela's Hathigumpha inscription which refers to the king Kharavela as 'causing the people to be pleased and attached to him.' (rañjayati pakatiyo), Epigraphia Indica 20 (1929-30), no. 7, p. 79; and the Junagadh rock inscription of Rudradāman which claims that his subjects were attached to him (prakrti anuraktena). Epigraphia Indica 8 (1905-6), no. 6, p. 44.

${ }^{61}$ Corpus Inscriptionum Indicarum 3 (1888), no. 14, p. 59.

${ }^{62}$ Corpus Inscriptionum Indicarum 3 (1888), no. 21 , p. 93.
} 
Harṣa as 'attached' to his splendour (pratāpānurāgagata). ${ }^{63}$ And finally, an eighth-century inscription from Western India refers on the one hand to the hereditary servants of a dynasty as 'attached to the king through affection' (anurāgānurakta), ${ }^{64}$ and later refers to sāmantas paying obeisance to the king through the 'attachment produced by his splendour' (pratāp-änurāga-pranata-samasta-sāmanta).${ }^{65}$

Viewed as a process, anurakta denoted the attraction or drawing of one person to another; courtly representations typically mention virtues and powers which attract others to oneself. Virtues generally had the effect of making one 'attractive'-literally 'pulling' others towards oneself. Numerous inscriptions mention the bonds of service and affiliation being based on the attraction or attachment to the qualities of one's lord. A typical attribute of kings which attracted others, for example, was 'splendour' (pratāpa) as cited in the examples above. A later inscription refers to the Kalinga king Anantavarman as having the entire circle of vassals (sämantas) attracted to him by virtue of the excellence of his threefold power (śaktitrayaprakarșānurañjita). ${ }^{66}$ But inscriptions often make more general reference to the virtues of kings and lords. A southern Śīlāhāra grant of the eleventh century describes a Rāsțrakūṭa king as 'attractive by his royal qualities' (nrpagunaramanīya). ${ }^{67}$ In the famous Mandasor inscription which recounts the emigration of a guild of silk weavers to Daśapura and their request for favour from the reigning king of the region, the silk weavers proclaim that they are 'attracted to the virtues' (gunāpahrta) of the king. ${ }^{68}$ Together, these inscriptions make explicit one of the chief goals of self-cultivation and moral perfection-to gain the attachment of others in the world. The texts on polity like the Nĩtisāra and Arthaśästra exhort the king to develop virtues within himself which are called abhigämika gunas, literally, 'qualities which invite'. ${ }^{69}$ Having inviting qualities would attract dependents and allies to a lord. A seventh-century inscription of the Kāmarupa king Bhāskaravarman is explicit about it: the king is

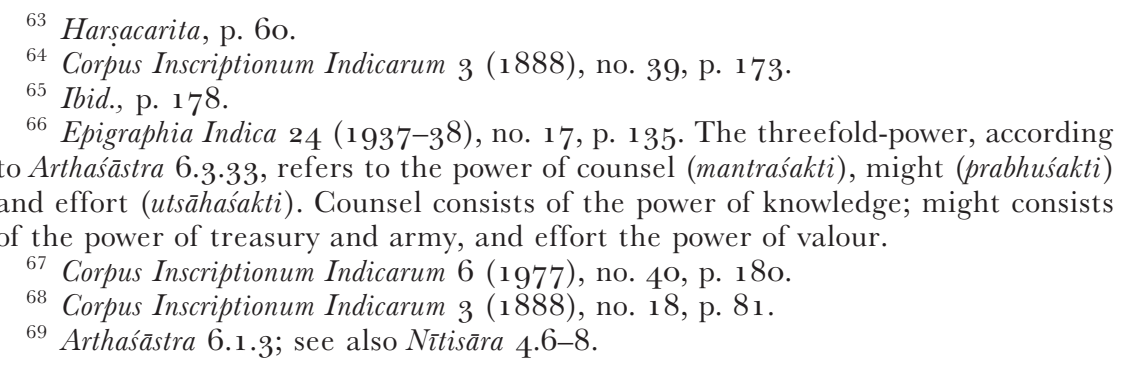


described as having people 'attached to his inviting qualities' (ābhigämikagunānnurāga $).{ }^{70}$ In an eighth-century inscription, even the goddess of fortune is attracted to the inviting qualities (abhigämika gunas) of the Gurjara king Ahirola. ${ }^{71}$

\section{Attachment as Subjection}

What constituted this attachment? In the inscription of Ahírda, the poet tells us that it is the mind (manas) of Lakșmi that was fervently attached to the king. ${ }^{72}$ In the preceding discussion we learned that it was the mind which oversaw, through its mastery of the senses, the self's relation with the external world. If we see the problem of attachment as one not simply between the self and the world but between selves, then we may see the role of the mind in courtly discourses slightly differently. The mind was the 'zone of engagement' for the dynamics of attachment and detachment which articulated the relations of courtly selves. As the locale of social dispositions and sentiments, the mind was the place where affiliation resided, and where the battle of affections took place. The texts most often speak of the attachment of people's minds as a sort of 'capturing'. We may see early examples of this in some of the hymns of the Atharvaveda, the methods of which were later appended to the courtly knowledges of the Arthaśāstra and Kāmasūtra as 'secret' (aupanișadika). In one rite to attain 'victory' in the assembly $(s a b h \bar{a})$, the performer was to eat milk-porridge, take hold of the pillars of the assembly hall and pay the assembly hall respect while reciting the following hymn if your mind (manas) has wandered to a distance (parägatam) or been tied (baddham) here or there, then we draw it here (vartayamasi). May your mind (manas) take delight (ramatām) in me'. ${ }^{73}$ In another Atharva hymn which sought to procure harmony within the assembly, the performer was to chant

\footnotetext{
${ }^{70}$ Epigraphia Indica 19 (1927-28), no. 19, p. 118 . See also the eighth-century inscription of the Gurjara king Ahirola which claims that even the goddess of fortune is attracted to the inviting qualities (abhigamika gunas) of the king, Corpus Inscriptionum Indicarum 4 (1955), no. 24, p. 105.

${ }^{71}$ Corpus Inscriptionum Indicarum 4 (1955), no. 24, p. 105.

72 Ibid. See also Corpus Inscriptionum Indicarum 4 (1955), no. 12, p. 41.

${ }^{73}$ Atharvaveda 7.12. For practices associated with this hymn, based on Keśava's commentary on Kauśikasütra, see M. Bloomfield, Hymns of the Atharva-Veda: Together with the Extracts from the Ritual Books and the Commentaries (Oxford: Clarendon Press, 1897), p. 543 .
} 
We cause your minds, vows, plans to bend (namāmasi). Those devoted to other purposes (vivratā) we cause to bend (namayamasi). I seize your minds with my mind (grhnāmi manasā manāms). Your thoughts will follow my thoughts (citamanu cittebhireta). I place your hearts (hrdayanin) in my control. Direct yourself towards me after my course. ${ }^{74}$

These hymns, connected with secret rites, were only to be employed in special circumstances, when policy and strategy as detailed in the bulk of the Arthaśāstra and Kāmasūtra failed. In a peculiar way they thus reveal quite well the unveiled ambition of courtly practice. Although they do not use the term anurakta, they anticipate its logic by referring to the untying of the opponent's mind from its current mooring and drawing it to oneself where it would 'take delight'. The goal of policy and strategy at court was to bend and capture the mind (mano grah) of others and thereby to cause them to submit in some way to oneself. The imagery of 'seizing' another's mind or 'causing it to bend' is highly significant. The comportment of the body was ultimately linked to the disposition of the mind, and becoming attached to someone entailed bodily gestures which reflected the condition of the mind. One bowed because one's mind was drawn in a deferential manner toward another person. Attachment was envisioned as a 'leaning toward', or 'inclination' of the mind, which led to the inclining of the body in the direction of another. So it is perhaps not surprising that in the eighth-century inscription from India cited above, feudatories are said to bow down to their lord from

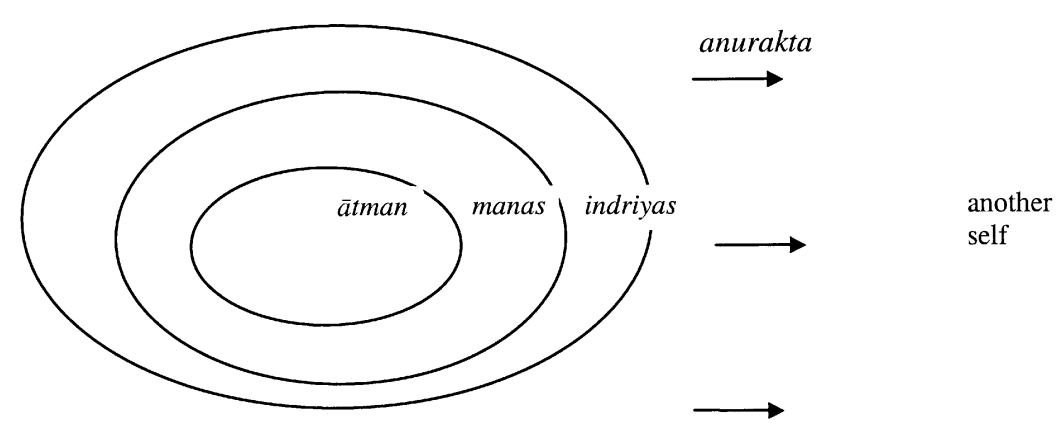

Figure 2.

\footnotetext{
${ }^{74}$ Atharvaveda 6.94. This hymn appears with six others which are together designated as 'designed to bring harmony' (sāmmanasyāni) and is associated with rituals which include eating the pickled flesh of young calves. For details, see Bloomfield, pp. $360-1$.
} 
excessive attachment to his splendour (pratāp-ānurāga-pranata) ${ }^{75}$ The self in such a situation may be pictured in Figure 2, keeping in mind our earlier image of the self. In this representation, the internal order of the self we saw above is disrupted as the self literally gravitates through attraction toward another. Attachment meant the partial surrender of one's own self-mastery, through a re-direction of the disposition of the mind and the external 'instruments' (karanas) which it ruled (the senses as well as the motor organs) to the service of another being.

This submission entailed 'control' of others, a concept indicated in Sanskrit by the term vaśa, often translated as 'influence' or 'subjugation'. The Atharva hymn cited above speaks of placing the heart of one's opponent 'in the control' (vaśeșu) of the reciter. Subjugation could be exercised over a number of domains-first and foremost of which was one's own self. We hear of rulers as being 'self-controlled' (ätmavaśa), ${ }^{76}$ a condition which presupposed, as we mentioned above, the conquest of the senses and the restraint of the mind. Conversely, attachment to pleasures, for example, is often said to entail a disorder - the control of the mind by the senses. In Harșa's Ratnāvalì, a woman is observed to be moving unsteadily during the Spring Festival because she is 'controlled by passion' (madanavaśa). ${ }^{77}$ The term vaśa also referred to the effecting or extension of one's wishes over another person, akin to the modern notion of 'influence'. A thirteenth-century inscription of the later Rāṣtrakūtas refers to a counsellor who exercised 'fascinating control (vaśikāram) over his friends'. ${ }^{78}$ The goal of royal policy, according to the Arthaśästra, was for the king to use the benefit of livelihood, along with his wealth and the army, to 'bring under his control' (vasikaroti) both his own party (svapaksam) and other parties (parapaksam). ${ }^{79}$ In reviewing the importance of danda Kautilya cites one school of thought which held that coercion was the most effective means for the entire polity to be 'brought under control' (vaśopanayanam) ${ }^{80}$ While Kautilya disagrees with the proposition that coercion should be the sole instrument of rule, he hardly differs on the goal of policy. Bringing other parties under one's control was most effectively achieved through peaceful

${ }^{75}$ Corpus Inscriptionum Indicarum 3 (1888), no. 39, p. 178.

${ }^{76}$ Corpus Inscriptionum Indicarum 3 (1888), no. 14, p. 59.

77 Harsa Ratnāvalī ed. and trans. C. R. Devadhar and N. G. Suru (Poona: Ganesh Printing Works, 1925), 1.12+.

${ }^{78}$ Epigraphia Indica $13\left(1915^{-16)}\right.$, no. 3a, p. 20.

${ }^{79}$ Arthaśástra 1.4.2.

${ }^{80}$ Arthaśástra 1.4.6. 
means, as when a vita remarks at a salon of refined men (gosth $\bar{\imath})$ in the Dhürtvitasamvāda, that giving gifts was a means of bringing the people of the world in general (lokasya), but particularly courtesans, under one's control. ${ }^{81}$

The language of capture and seizure, however, indicates that relations of attachment were also in part agonistic. Attachment was most essentially a submission of one mind to another. It compromised the relative autonomy of the servant and secured the relative autonomy of the master. Expectedly, then, 'attachment' could also be achieved through the direct or indirect threat of force. When an eighthcentury inscription from Western India describes sammantas who bow down to king Kharagraha because they had been 'violently subdued (sarabhasavaśikṛta) by excessive attachment (atiprakrștānurāga) (for him),' more than a hint of coercion may be implied. ${ }^{82}$ One of the ends of the policy of war in the niti texts was the submission of the defeated king to the victor which was expressed as an attachment of the defeated king's self/mind as ruler of its own organs/instruments with their external domains, to a new lord.

We may sum up the discussion as follows. The relations between men at court were characterized by strategies which entailed drawing others to themselves by attracting or 'capturing' their minds. In such relations the self remained relatively unattached, with the proviso that its own autonomous agency was often enjoyed by virtue of its attachment to even higher agencies. The fear of dependence was an anxiety behind courtly strategy. The Mudrāāakșasa says that acting in the interests of others causes one's own interests to suffer and thus causes one to become servile. And being dependent on another, it was impossible to experience the taste of pleasure. ${ }^{83}$ The goal of royal policy, in a sense, was to limit the internal masteries of all servants, companions and rivals within the king's sphere of mastery and thus gain their submission or attachment, while remaining relatively 'unattached' vis à vis these relations himself.

The same antagonism could potentially underlie the servant's relation with his lord. As Hāla puts it, 'though being dependent on his own will (ätmavaśa), a good man of noble birth may submit to another, even if hated, with the complexion (or attachment—rāga)

\footnotetext{
${ }^{81}$ Dhūrtavițasamvāida $29^{+}$.

${ }^{82}$ Corpus Inscriptionum Indicarum 3 (1888), no. 39, p. 177.

83 Viśăkhadatta, Mudrārāksasa, ed. A. Hillebrandt (Breslau: H. and M. Marcus, $1912), 3 \cdot 4$.
} 
of his face unchanged, and follow his wishes. ${ }^{84}$ The nitti texts recommend that the king placate his dependants, for treating them with improper respect could potentially lead to being abandoned or even being killed. ${ }^{85}$ The courtier's advancement through circles of the court and his gaining of superior favour could often entail antagonistic policies toward his lord, as when in the Purusapariksa the prince Malladeva, who attends the court of Jayacandra, leaves the court of his lord in order to challenge him to battle in the hope of gaining the king's favour by a display of valour. ${ }^{86}$ The jackal-minister Damanaka in the first book of the Pañcatantra, when he sees his own sovereign Pingalaka's weakness, confides to his friend that 'this very day I will catch him while he is overcome with fear and by the power of my intelligence bring him under my control (prajñäprabhāvenātmīyam karisyāmi $)^{8}{ }^{87}$ In these cases an internal constituent of the kingdom, one of the king's own 'instruments', attempts to exercise his will over his master, and is ultimately, as the story unfolds, successful.

The mutual antagonism which could underlie relationships at court is best revealed, I would submit, by the persistent ambivalence to attachment and dependency in the aphoristic literature. Servitude, devotion, and attachment were on the one hand elevated to the most perfect of virtues and on the other denigrated as the basest of conditions. It was better to go to the forest than to be dependent on another. Moralists of the court decry the pathos of servitude and denigrate lords for their pride and cruelty, while at the same time blaming servants for their greed. The apparently simple posture of devotion that a servant was to have toward his lord, along with the reciprocal disposition of favour the lord was to display toward his dependant-relations which formed the very sinews of affiliation at court-were undergirded by complex antagonisms which the language attachment was fully capable of sustaining.

\section{Courtship and the Language of Paramours}

Before turning to the 'ideological' dimension of courtship as it is represented in courtly poetry, it will be useful to sketch a brief reconstruc-

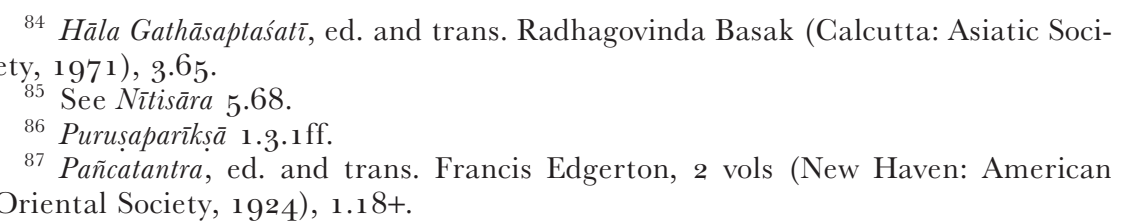


tion of the contexts in which 'courtship' may have actually occurred. In the higher forms of marriage laid out in the śástras, to be practised by the upper varnas and deeply enmeshed in the acquisition and perpetuation of property and/or authority, prospective wives were to be secured by arrangement, through the 'selection' (varana) and/or 'gift of a maiden' (kanyādāna). Marriage was an institution explicitly used to build political alliance and open avenues of economic exchange between 'houses'-families as politico-economic units. For the ruling elite of medieval Indian courts, of putative kșatriya lineage, selection and marriage was the most important method of sealing political alliances between kings. Wars between rival kings were often concluded with the defeated house offering women in marriage to the victors. The practice of kanyādāna, as Thomas Trautmann has demonstrated, tended to establish the superiority of the groom's family over that of the bride. ${ }^{88}$ Even for others of standing, selection seems to have been the dominant form of marriage. Vātsyāyana begins his book on 'acquiring a wife' with a discussion not of the relations between the nayyaka and $n \bar{a} y i k \bar{a}$, but between the naggaraka and the family of the prospective bride, implying the context of varana/kanyādāna.

Among ksatriyas marriage was in some cases arranged through a svayamvara, or 'self-choice', where the daughter of a superior king chose from a group of suitors drawn from allies or powerful underlords of her father. The svayamvara also ended with a 'gift of a maiden' but may not have indicated the subordination of the giving king. ${ }^{89}$ The svayamvara is an important event in the Mahäbhärata, and became an increasingly popular theme in later kāvya, particularly the story of Nala and Damayantī. ${ }^{90}$ The svayamvara would seem to offer one context for the display of male virtue vaguely akin to conceptions of chivalric romance in medieval Europe. It was certainly not, however, the dominant mode of brokering marriages among the courtly elite, and seems to have been more of a literary theme than anything else. The romance which

\footnotetext{
88 Thomas Trautmann, Dravidian Kinship (Cambridge: Cambridge University Press, 1981), p. 26.

${ }^{89}$ See Naiṣhadhĩyacaritam 16.10-12.

90 Noted by Johann Meyer, Sexual Life in Ancient India (New York: Dorset Press, 1995), p. 78, n. 3 and B.N.S. Yadava, Society and Culture in Northern India in the Twelfth Century (Allahabad: Central Book Depot, 1973), p. 7o. In addition to Śrīharṣa's Naishadhĩyacaritam versions of this story include the Nalodaya of Kalidāsa (uncertain date and ascription); the Nalacampi of Trivikrama-Bhatta (9th century); the Naișadhānandanātaka of Kṣemīśvara (9th-1oth century); the Sahrdayānanda of Krṣnānanda (1 $3^{\text {th }}$ century); and the Naläbhyudaya of Vāmanabhațabāna $\left(15^{\text {th }}\right.$ century).
} 
unfolds in the Nala/Damayantī story is peculiar in that the protagonists fall in love and begin to pine without ever having seen one another, a fact which highlights the role of 'fame'-exhibited through female beauty as much as male prowess-in drawing families together in marriage, rather than the rudiments of courtship.

In both the kanyādāna and svayamvara, as in the more embracing rites of 'selection' (varana) of which they were variants, the scope for premarital courtship was limited. Only one form of the sāstrically sanctioned marriages, the gandharva, was understood as the culmination of the mutual affection of the bride and groom and obviously entailed pre-marital courtship. ${ }^{91}$ Whatever the prevalence of this form of marriage, the context of marital courtship presumed in the bulk of the Kámasütra's discussion of the acquisition of a wife revolves around 'creating confidence' (visrambhanam) in the bride (kanya), during the first days after the marriage ceremony. ${ }^{92}$ This was no doubt the typical context for courtship, and one that was undoubtedly complicated by the existence of co-wives and other women in the house sexually available to the patriarch. Both the Kämasütra and later manuals like Kokkoka's Ratirahasya recommend three nights of celibacy after the marriage ceremony, to which Vātsyāyana adds another seven, before the groom was to begin wooing the bride. ${ }^{93}$ Both texts are emphatic that the husband avoid rash or untimely sexual advances without first gaining the confidence of the bride. ${ }^{94}$ This is because, we are told, when a man approaches a woman suddenly, he engenders fear, disgust, dejection and is detested in her mind; and when she feels no affection, she becomes ruined by anxiety, she may perhaps come to hate men in general, her husband, or may then go

${ }^{91}$ Vātsyāyana begins the third chapter of his book on acquiring a wife by advising the man who lacks the proper qualifications for the marriage negotiation, not to enter into the selection ceremony because he would not be able to obtain a maiden (Kämasütra 3.3.1 ff). In this case he was to win her over himself (svayamevamanurañjayet) by courting that began in her childhood. Vātsyāyana then cites Ghotamukha's opinion that this type of wooing (samvananam), in a girl's childhood, pure and according to dharma, is praiseworthy (Kāmasütra 3.3.4). Following chapters provide various strategies for the cultivation of a mutual attraction between the prospective partners before marriage. The gändharva marriage, according to Vātsyāyana, was the superior form because it was attained without much difficulty, without a ceremony of 'selection' (avarana), and was based on mutual affection or attachment (anurāgätmakatvāt) which was said to be the 'fruit' of all marriage in any event (Kämasütra 3.5.29-30).

${ }^{92}$ Kãmasūtra 3.2.1.

${ }^{93}$ Kāmasūtra 3.2.1; Kokkoka, Ratirahasya ed. Ramananda Sharma (Varnasi: Krishnadas Academy, 1994), 1 1.8.

${ }^{94}$ Kāmasūtra 3.2.4-6; Ratirahasya 11.8. 
to another man. ${ }^{95}$ It is concluded that a man who knows how to win the confidence of women, increase their attachment, and cause their affection toward him, becomes beloved among them. ${ }^{96}$ Post-marital courtship suggests a clear recognition that marriage and affection, though related, were quite distinct. Courtship formed a way of 'regulating' the initial period of marriage, one potentially fraught with tension, given the context, typical among the elite, of polygamy and concubinage. The result of courtship, 'affection' (anurāga) was considered to be a 'fruit' of marriage (vivāhānām phalam) rather than marriage being the culmination of courtship and affection. ${ }^{97}$

Indeed, if we follow the texts on kamma, it is clear that the conjugal relation formed only one of the potential contexts-and perhaps not the preferred one-for courtship. After recommending the norm of same-caste liaisons with unmarried virgins for the purpose of procreation, Vātsyāyana says that relations with lower varnas not fully rejected from the social order, courtesans, and widows or women once married, being neither forbidden nor commended by the śāstras, may be entered into for pleasure (sukhārthtvāt).$^{98} \mathrm{On}$ this basis, Vātsyāyana concludes that nāyikās were of three basic varieties-unmarried maidens $(k a n y \bar{a})$, women once married who seek again the company of a man out of wedlock (punarbhiu), and courtesans (veśy $\bar{a}) .{ }^{99}$ Excepting virgins of the same caste married for children, other women of these categories were to be enjoyed for pleasure alone.

Judging from subhạsita literature, for many men of rank the courtesan was the preferred liaison. Relations with courtesans (ganikā), the highest rank of prostitute, entailed elaborate courtship, explicitly detailed in the Kämasütra and the theme of numerous literary works, including an entire genre, the bhāna monologue play. Many aphorisms compare the courtesan favourably with the wife: in contrast to courtesans, according to one saying, wives had the uninterrupted course of their youths destroyed by continually having children, had no respect for the games, diversions, and sentiments of the salon of

95 Kāmasūtra 3.2.43-4; repeated Ratirahasya $11.21-2$.

${ }^{96}$ Kāmasūtra 3.2 .41 ; repeated, with slight variance, in Ratirahasya $\mathbf{1} 1.20$.

${ }_{97}$ Kämasūtra $3 \cdot 5 \cdot 30$

98 Kāmasūtra $1 \cdot 5 \cdot 3$.

99 Vātsyāyana goes on to engage various contemporary authorities (no longer extant) over the question of other categories of nāyikās, implicitly conceding two more varieties-the married woman enjoyed for some other purpose (paksiki), and those of the 'third nature, (trit̄̄yaprakrti), classified as neither man nor woman. Kāmasütra $1.5 .5,27$. Varieties of tritīyaprakrti are discussed in more detail at Kämasütra 2.9.1-8, in connection with the practice of auparistakam. 
refined men (gosthi $)$, avoided manners of the courtesan, and were devoid of passion. ${ }^{100}$ Numerous sayings recommend that the perfect wife strive to be like a prostitute in bed. ${ }^{101}$

Another context of courtship for men of rank, but particularly princes, must have been the affections they received from palace women as they reached maturity. Such episodes are mentioned in the accounts of princely lives contained in the Buddhacarita, Raghuvamisa, and Kädambari and other texts. Though these descriptions are intended to underscore the attractiveness of the young prince, they also point to an important context for sexual liaisons which were not structured by the interests of marriage. Such episodes in the young prince's life, Śākyamuni's case only being an extreme example, were meant to demonstrate his ability to master his senses and remain ultimately aloof from these attachments. King Agnivarna of the Raghuvaimśa, whose sad fate was mentioned above, begins his life of pleasure in his youth at the palace, and never emerges from it. These episodes point to an important dimension of courtship in the life of the court which we shall be exploring in the remainder of this essay. Courtship introduced young men to some of the most important 'lessons' and 'rules' of courtly life as a whole. It formed a perfect 'training ground' for the virtuous. After learning the sciences, young princes were 'tested' in the company of women before they assumed the throne. In courtship they were to perfect the controlled display and interpretation of dispositions, exhibit courtesy, generosity and other virtues, and most importantly, exercise self-mastery at all times.

Whatever the context of courtship, there is a tendency in its representation, in both the texts on poetics and the poetry itself, to dissociate lovers from their contexts. We tend to find a world of hermetically sealed lovers who solicit (prārthana), create confidence (visrambhanam) and win over (jayan) one another through various strategems. The context of the courtly world, however, may be dimly discerned by attention to the dynamics of lovers themselves. It will be suggested here that the ubiquitous representation of this theme in courtly poetry may thus be understood in a new light, as a tableau onto which courtly society projected its larger concerns and anxieties, particularly those around the problems of autonomy and dependence

${ }^{100}$ Ganikārrttasangraha 28. Judging from the sources, the institution of marriage formed no bar in their relations with them. One need only think of Śudraka's famous play, the Mrcchakatika, where the hero, the brahmin Cārudatta, falls in love with the courtesan Vasantasenā.

${ }^{101}$ Ganikāurttasañgraha 18-21. 
which we have outlined above. The prominence of erotics in the literature of the courts of medieval India has much to do with the fact that 'courtship' became the arena where the ethical problems of courtly life were reflected upon and learned through the 'game of love'. From this vantage point, the rise of the dominance of this theme in courtly poetry is quite clearly related to and explicable by the spread of 'feudal' ties of dependence in medieval India.

The link between erotics and the wider problems of courtly life as sketched in previous sections of this essay is in the first place underscored by the fact that a number of the key terms used in this discussion-anurāga, vaśa, mano grah-are usually encountered first by modern scholars of Sanskrit literature not to describe political, but instead erotic relationships. This congruence of language deserves serious consideration, for the agonism of affection is even more apparent in the discourses on courtly love. Perhaps the most obvious parallel is the explicit martialization of courtship. This takes numerous forms. The most common images connect the bodies and gestures of lovers to weaponry in general, as when Bhartrihari says that a woman's sidelong looks, darting glances with raised eyebrows, soft speech, shy laughter, and playfully indolent movement all constitute at once their ornaments (bhüsanam) and their weapons (ayudham). ${ }^{102}$ More particular is the iconography of Kāmadeva, the bowman of love, who pierces the hearts of lovers with his flower arrows. This set of comparisons forms among the most popular images of courtly kāvya. The most developed imagery is resolved around the eye, with the eyebrow compared to the bow, the eyelash to the bowstring and the glance to the arrow. In a typical example from Vidyākara's anthology, the female's glance (viksitam) is likened to a poison arrow, bringing paralysis, dizziness of mind, fever, and in the last event, loss of consciousness following Vāstyāyana's stations of desire. ${ }^{103}$ Desire in Sanskrit erotics was considered to be afflictive, not simply as a generalization of the self's relation to the world (as it has been read by scholars of religion), but more specifically as violence of one person against another. Once again, a hymn from the Atharvaveda makes this explicit. To gain success in love, one could perform a rite incanting 'with that arrow, winged with longing (adhīparnām), whose shaft is love (kāmaśalyam), whose neck is resolve (saṃkalpakulmalām)—

102 Subhāsitatriśatī 2.3.

103 Vidyākara, Subhāsitaratnakośa ed. D. D. Kosambi and V. V. Gokhale (Cambridge, Mass.: Harvard University Press, 1957), 496. 
with that Kāma, well aimed, I shall pierce your heart. ${ }^{\text {,104 }}$ Vātsyāyana remarks that erotic pleasure takes the form of a combat (kalaharüpam) because it is essentially a contest (vivādātmakatvād) and because of its contrariety (vāmaśilatvāt), which his commentator Yaśodhara explains as arising 'because man and woman each tries to accomplish their own goal (svārthasiddhaye) by overcoming the other (parasparābhibhavena). ${ }^{105}$

The Kämasütra makes it clear that the goal of this combat was gaining the attachment of one's opponent. Creating confidence and trust (visrambhanam, viśvāsa) and soliciting (prärthana) were all embraced within the larger strategy of 'winning over' a lover to oneself, or what Vātsyāyana calls literally 'causing one to be attached' (anurañjayati). ${ }^{106}$ The idea was to gain the attachment of one's paramour without oneself becoming attached. For men, according to the Mrcchakatika, "no attachment ( $r \bar{a} g a)$ should be had to women; women insult the attached man (raktam purusam); only the woman who is herself attached (raktaiva) should be enjoyed. ${ }^{107}$ In preparing for courtship, the idea was to make oneself 'attractive'; the suitable nayyaka, just like the king, was to possess qualities which were abhigamya, 'inviting', and caused others to move toward him. ${ }^{108}$ The courtesan Vasantasenā repeatedly remarks in the Mrcchakatika that she is attached to virtues (guneșvanurakta) of Cārudatta. ${ }^{109}$

The drawing of a lover to oneself, just as drawing a dependant, and gaining his or her attachment, was fraught with potential antagonism. Each lover tried to 'catch' the mind of the other, and having done so, to exercise 'control' or 'influence' (vaśa) over it. Typical are two ninth-century graffiti inscriptions from Sigiriya in Sri Lanka addressed to paintings of heavenly maidens: 'Having looked at you my mind is as if subdued (visi); by the mere sight of you I am enslaved'; You have bent and subdued (visi) my mind. ${ }^{110}$ Wives were recommended to seek control over their husbands, particularly in

104 Atharvaveda 3.25 .2 .

105 Kämasütra 2.7.1 and comm. The description of lovers bears resemblance to the well-known definition of an enemy in the texts on polity. The enemy, according to Kāmandakī, was one who pursued the same goal as the self (ekārthābhiniveśa), Nìtisāra 8.14

${ }^{106}$ Kämasūtra $3 \cdot 3 \cdot 2$.

107 Mrcchakatika $4 \cdot 14$.

108 Kämasūtra 6.1.11.

109 Mrchakatika 1.6 passim.

110 Sinhala vis̄ = Sanskrit vaśa. Sigiriya Graffiti, nos 273, 166. See also nos 211, 494,547 . 
the polygamous context. Vātsyāyana says that a king or minister's daughter who knows the sixty-four arts will control her husband (svavaśe kurute patim) even if there are a thousand other women in the inner quarters (antahpuram). ${ }^{111}$ Exercising control over one's husband also entailed mastering the other women of the household, and Vātsyāyana advises the young wife to conquer her own anger and cultivate herself in accord with the kāmaśästra in order to stand above (adhitisthati) and control (karoti vaśyam) her co-wives and her husband. ${ }^{112}$ Conversely, the nayyaka was also encouraged to bring a woman under his control. In his disquisition before the gost thi, the vita Devilaka is asked the question of how one can bring under one's control (vaśy ā) a woman who does not disclose any sign of desire (kāmalinga), who says 'enough', who does not draw near, and avoids one at the proper time. The vita approves of this question, and responds that one must first know the nature of the woman and then adopt a suitable means accordingly. ${ }^{113}$ When a man could not achieve this through the normal methods recommended in the kāmaśästra, he could have recourse to 'covert methods' (aupanisadikam) which included the use of various special substances (dravya) and rites from the Atharvaveda. The goal of many of the aphrodisiacal recipes was to enable a man to 'exert influence' (vaśikaranam) over a woman. ${ }^{114}$ The significant aspect of these formulae for the purpose at hand is not their 'secrecy', but quite the opposite, their open revelation as to the ambitions and strategies of courtship as a whole.

\section{The Courtesan as Icon}

The figure of the courtesan in the discourses of the court is worth pausing over, as among the non-conjugal sexual relations permitted by the sasastras for man of rank, the courtesan formed the most reflected upon in the didactic literature. It would seem that the cour-

\footnotetext{
${ }^{111}$ Kämasūtra 1.3.22. See also Nātyaśāstra 24.224 for the woman whose husband is under her control (svādhinnabhartrkāa).

${ }^{112}$ Kāmasūtra 4.2.90.

${ }^{113}$ Dhürtavitasamivāda $46+$. Devilaka recommends forcible seizure in the case of a proud woman.

${ }^{114}$ Kämasütra $7.12-3$ ff.; $25^{-28} ; 31-35$. The whole of the fourteenth book of the Ratirahasya is devoted to vaśikaranam, as well as specific mantras for various types of women in the sections on nāyikabheda. See Ratirahasya 1.23+; 14.1 ff. Also s.v. in Ram Kumar Rai in his Encyclopedia of Indian Erotics (Varanasi Prachya Prakashan, 1983) which draws heavily on Kalyānamalla's late-fifteenth century Anañgarañga.
} 
tesan was the $n \bar{a} y i k \bar{a}$ par excellence for those at court. ${ }^{115}$ The courtesan is peculiar in that though inferior in rank to the wives and maidens of upper caste men, she at the same time could largely operate as an autonomous agent at court, unattached to the juridical identity of any male. She was capable of gaining the attachments of men and these attachments could in some cases have notorious and weighty consequences. Courtesans sought to make their own way in courtly circles through the exercise of very real capacities amongst these affiliations. At one level, the courtesan differed little in the kinds of capacities she possessed from the various men who surrounded her (though the breadth of her capacities were considerably restricted). The discourse on courtesans is important because while they are often decried as being inferior to women of good standing, numerous aphorisms make the point that the courtesan was merely a sub-species of women as a whole, particularly women of the court. Courtesans are said to be better than women of good birth (kulastrī), who are rarely chaste. ${ }^{116}$ Here the defamation of the courtesan connects up with a wider denigration of women as 'fickle' and 'dangerous'. ${ }^{117}$ And given what we know from Vātsyāyana's account of women enjoyed for pleasure outside of marriage, and the potential motives and dangers of such liaisons, we can easily see the basis for such perceptions.

In Vātsyāyana's list of qualifications for a male lover or nāyaka, it is noted that he should be of 'independent means' (svatantravrtti), he should not be subjected to women (na āsām vaśaga), and, finally, he should be unattached (anavasankī). ${ }^{118}$ The courtesan is advised by Vātsyāyana to put an end to all three of these conditions. Vātsyāyana repeatedly says that the courtesan was to cause attraction (anurañjayet) and attachment (sakta), even excessive attachment (atisakta) in her lover and thus bring him under her will (vaśa). ${ }^{119}$ She was then, through various means, to extract as much wealth as possible from him. The courtesan, by draining her paramour of his wealth, destroyed his financial independence and brought him under

\footnotetext{
${ }^{115}$ It is only in his book on courtesans that Vātsyāyana lays out the general characteristics of the nāyikā and nāyaka.

${ }^{116}$ Ganikāurttasangraha 603-4.

117 The bad qualities of the courtesan are often considered indistinct from those of women in general, who are seen as the larger species to which they belong. See Ganikāurttasangraha $243^{-4}, 359^{-416}, 5^{1} 4^{-1} 7,5^{2} 5$, et al..

${ }_{118}$ Kämasütra 6.1.12.

119 See for example Kāmasūtra 6.4.43.
} 
the control of others through debt and penury-she turned him from a nayyaka to, in the worst cases, a vita. Bereft of his independence, the paramour was then summarily dismissed.

The chief means of gaining the attraction of her customer, according to Vātsyāyana, was dissemblance. Vātsyāyana suggests that courtesans go to men partly for pleasure, but more importantly for livelihood, which requires them to make their affections seem natural (svabhävika). ${ }^{120}$ She was to give her customer the impression that she was attached to him in order to gain his attachment to her. ${ }^{121}$ One of the most notable features of the aphoristic literature on courtesans is its obsession with their deception. Some maintained, of course, that her affections were genuine, most notably her faithful agent, the vita. In one play a vița named Devilaka resolves a controversy at a salon (gost $h \bar{\imath}$ ) regarding the methods of detecting a courtesan's sincerity. ${ }^{122}$ Devilaka is adamant that the sentiments of courtesans were genuine, as they were manifested by physical states on their bodies. These physical states-horripilation, crying, sweating-were deemed involuntary bodily effects in the texts on dramaturgy. But courtesans, others maintained, were just like actors and could induce these states in their bodies. ${ }^{123}$ Indeed, the courtesan was an expert, according to Dāmodaragupta, at theatrical presentation (abhinaya) which in her case took the form of praiseworthy speech (stüti), gesturing with her limbs (gātrabhanga), decoration (vinyāsa) and indignation $(m \bar{a} n a) .{ }^{124}$

The courtesan was an expert in displaying desire in different ways. Her agent, the vita explains to the members of the salon that feminine desire (kāmitam) could be classified as either 'open' (prakāśa) or 'concealed' (pracchanna). ${ }^{125}$ Wives (kulavadhū) concealed their desires, while courtesans (veśyavadh $\bar{u}$ ) could either openly display or hide their affections. Anticipating the question of why the courtesan's expres-

120 Kämasūtra 6.1.1-3. Much of Vātsyāyana's subsequent advice to courtesans is aimed towards creating confidence in her lover.

121 Kāmasūtra 6.2.2.

122 See Dhürtavitasañvāda 31, 32, 43.

123 Kuttanimata 312 , cited in Ganikärrttasañgraha 219. See also Kuttanimata 98 and Dhūrtavitasamvāda 31-2. For other references to courtesans as actresses, see Ganikāvrttasàigraha 222-9.

${ }^{124}$ Kuttanimata 657 , cited in Ganikāvrttasangraha 210 . These attributes correspond to the four modes of theatrical conveyance-vācika, āngika, āhärya and sāttvika-as set out in Nätyaśāstra 6.23. See the commentary on Kutṭañmata 657 which cites the Sāhityadarpana.

${ }^{125}$ Dhürtavitasañvāda $53^{+}$. 
sion of passions, which after all was permissible, would be concealed, the vita continues that various types of men-men adored previously (pürvasamstūta), favourites of the king (rājavallabha), those who have done some good for them (krtopakāra) or were gentle (anrśamsa) and devoted (bhaktimān) to them, or who showed respect to their madames (veśyajananisevaka)—had to be served for her own interests even if she did not seek them out. In such cases the open display of affection was 'feigned' (krtaka). But when a courtesan sought the favours of a man secretly he had obtained the rarest reward of his life, for this was a true reflection of her desires: 'concealed love, growing out of attachment (anurāga) alone, and having little fault (alpadosa), is pleasing indeed in the case of courtesans'. Of course, Devilaka's optimism here is undermined by the elaboration in the erotic manuals of ever greater forms of dissemblance on the part of the courtesan.

The perennial debate about the authenticity of the courtesan is significant in light of the foregoing discussion. It is curious that the moralists of the court would decry the courtesan, as the typical woman, as faithless and deceptive. The aphorisms constantly bemoan how they attract, ensnare, and capture the minds of men, exert their control over them, take their money and subject them to others. But such behaviours were more than familiar to the men of the court, as they were the very strategies open to them throughout their careers in the society of the good. In her labours of dissemblance and calculations of disposition the courtesan differed little from other agents at court. This is recognized in the occasional verses which compare courtesans to men at court. The secret attentions that a courtesan might show a man were thus comparable to the secret devotions that the followers of an old king showed to princes to gain their favour when the king was dying. ${ }^{126}$ Dependants and courtesans sell their bodies and words to anyone who will grant them favours. When it is said that 'like bitches (śunivva), courtesans will display hundreds of sweet words, eat dirt, perform bad actions and live by deceit (kapata) all for gifts (dānato)', ${ }^{127}$ the author might equally be speaking of the necessities of dependency. Indeed, according to the Müdrarākșasa, the courtier as one 'dependent on another' (parantatra) 'sold his body (śariram vikrīya) to the wealthy and lost all ability to discriminate. ${ }^{128}$

\footnotetext{
${ }^{126}$ Rājataranginī 7.619, as cited in Ganikäurttasangraha $18_{3}$. For other verses which compare the courtesan to men of the court, see Ganikãurttasangraha $462,482,484$.

${ }^{127}$ Ganikäurttasangraha 619.

${ }^{128}$ Muidraräkșasa $5 \cdot 4$.
} 
Numerous maxims also compare the courtesan to the king, whose policies were unpredictable, concealed, and notoriously, dangerous. ${ }^{129}$

One obvious conclusion that may be drawn from this invective against the courtesan and women in general in their role as nāyikās is that relations between lovers were often fraught with the same complex tensions as those of lords and dependants. Indeed, this is because at one level marriage, concubinage, and prostitution-the institutions that governed such relations-were in fact hierarchical relationships intimately associated with authority and property to begin with, which overlapped and were largely continuous with those which obtained between men. The contexts of courtship, in other words, were the contexts of the court, and were governed by the same principles and strategies.

This essay, however, has tried to suggest something more. Courtship had a special place in the world of the court, both as an institution and as an object of speculation and delectation. Courtship during youth allowed the men of the court to learn the strategies of conduct and forms of self-discipline necessary for their relations with men at court. The discernment and deployment of deception and indirection required in courtship prepared men for courtly existence as a whole. In a world where discerning the strategies of others and concealing one's own was a necessity due to inbuilt antagonisms, the process of courtship could provide no better training. And judging from the sources, continued success at courtship was an indication of one's self-perfection as a powerful man at court. In this capacity, the king had to represent himself as the most perfectly skilled player in the contest of love. This was achieved by the various liaisons in which he engaged, but extended to his relations with the feminine qualities of sovereignty, which were sexualized in precisely this manner. As one inscription describes a king, he was 'freely chosen by the goddess of fortune, her mind being overpowered by passion for all his attractive royal qualities and other excellences'. ${ }^{130}$

The conflictual elements in the discourses of courtship reveal the greater anxieties of courtly society around autonomy and dependence. It is not complete detachment from the world typical of the ascetic ideals which underlies the courtly discourses, but rather the

${ }^{129}$ Ganikāurttasangraha 436-8; also 529-36, 541 .

130 sakaläbhigāmikādigunānurāganirbbharamanasā svayam vrto rājalaksmyā: an eighthcentury Gurjara inscription. Corpus Inscriptionum Indicarum 4 (1955), no. 24, p. 105. 
idea of a hierarchical form of social engagement in which one subjected others by gaining their 'attachment' but remained relatively detached oneself. This was the underlying dynamic between lord and retainer which structured the affectations of courtly ethics. The problem, of course, was that each agent was typically caught in a web of such 'attachments'. Erotic love in part formed the palette upon which the underlying agonism entailed in relations of dependence and autonomy, wealth and poverty, service and mastery, was continually projected and thought about. Conversely, the particularities of this agonism, so essential to the representation of love in Sanskrit literature, may explain the prominence of this discourse as a whole at the courts of medieval India more than any civilizational conflict between the immanent and the transcendent. 
